\title{
First-year mortality in living donor kidney transplantation: twelve-year experience from a single center
}

\author{
๑D Özgür Merhametsiz, @Mehmet Emin Demir, @Murat Sevmiş, @Murathan Uyar, @Sema Aktaş, \\ (DŞinasi Sevmiş \\ Yeni Yüzyıl University, Gaziosmanpaşa Private Hospital, Department of Nephrology, İstanbul, Turkey
}

Cite this article as: Merhametsiz Ö, Demir ME, Sevmiş M, Uyar M, Aktaş S, Sevmiş Ş. First-year mortality in living donor kidney transplantation: twelve-year experience from a single center. J Health Sci Med 2021; 4(3): 252-256.

\begin{abstract}
Objective: The mortality was seen in the early period after kidney transplantation is one of the most undesirable consequences of kidney transplant treatment. This study was aimed to evaluate the factors affecting the $1^{\text {st }}$-year mortality in patients who underwent living donor kidney transplantation (LDKT) in our center.

Material and Method: Adult patients who underwent LDKT developed mortality within the $1^{\text {st }}$-year in our center between 2008 and 2020. Mortality group and the control group are compared according to donor and recipient characteristics. The risk factors that have an adjusted effect on $1^{\text {st }}$-year mortality after kidney transplantation were evaluated by cox regression survival analysis.

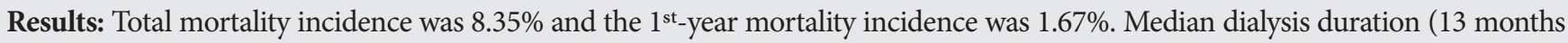
vs. 3 months) was longer in the mortality-group, $\mathrm{p}=0.022$. Cardiovascular disease (CVD) was more common in the mortality-group ( $50 \%$ vs. $31.1 \%$ ), $\mathrm{p}=0.037$. Median HLA mismatch numbers was higher in the mortality-group ( 4 vs. 3 ), $\mathrm{p}=0.027$. According to Model

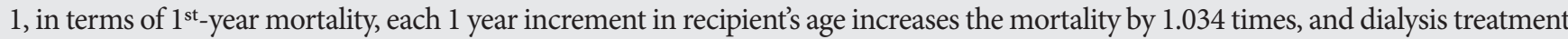
increases the mortality 2.5 times. According to Model 2 , in terms of $1^{\text {st-year }}$ mortality, each 1 year increment in recipient's age increase the mortality by 1.039 times, dialysis treatment increases the mortality 2.8 times and each 1 mismatch increase in human leukocyte antigen (HLA) mismatch numbers increases the mortality by 1.3 times. Receiver operating characteristic analysis showed that the moderate predictive power for recipient age was area under the curve (AUC) 0.734 ( $95 \%$ CI $0.623-0.844, \mathrm{p}<0.001$ ) and the weak level predictive power AUC was for HLA mismatch 0.639 ( $95 \%$ CI 0.519-0.759, $\mathrm{p}=0.030)$ in terms of $1^{\text {st }}$-year mortality.

Conclussion: This study presented that the $1^{\text {st }}$-year mortality results of our organ transplant center are similar to the national and international literature. We determined recipient age, dialysis treatment and HLA mismatch numbers as independent risk factors affecting $1^{\text {st }}$-year mortality after LDKT.
\end{abstract}

Keywords: Living donor kidney transplantation, mortality, dialysis

\section{INTRODUCTION}

Cardiovascular diseases (CVD) are the most common cause of mortality in patients with chronic kidney disease (CKD), followed by infections (1). While the uremic environment causes defects in both cellular and humoral immune system in CKD patients, chronic inflammation also leads to accelerated atherosclerosis (1). In CKD patients, risk factors such as advanced age, diabetes mellitus (DM), hypertension (HT) and hyperlipidemia (HL), which are risk factors for CVD, are more common than in the general population. CVD clinical presentations in patients with CKD may be in the form of atherosclerosis, ischemic heart disease (IHD), heart failure (HF), myocardial infarction (MI), sudden cardiac death, and peripheral vascular disease (PVD) (2). Kidney transplantation is the most preferred treatment method in CKD patients which ends the uremic environment and causes improvement in the uremic environment's negative consequences. Since kidney transplant patients also have CVD risk factors such as DM, HT and HL, deaths due to cardiovascular reasons frequently cause deaths after transplantation $(3,4)$. Immunosuppressive treatment causes more frequent infections in kidney transplanted patients than CKD and the general population, leading to infection-related mortality in these patients, which makes to ahead of CVD-related deaths (5).

The mortality was seen in the early period after kidney transplantation is one of the most undesirable consequences of kidney transplant treatment. Although 
improvement in kidney transplant treatment has led to a significant improvement in graft survival over the years, according to Turkish Society of Nephrology (TSN) registry reports, there has not been much change in the $1^{\text {st }}$-year mortality rates in the last ten years, and it has remained at a rate of 2-4\% (6-9).

This study was aimed to evaluate the factors affecting the $1^{\text {st }}$-year mortality in patients who underwent living donor kidney transplantation (LDKT) in our center.

\section{MATERIAL AND METHOD}

Yeni Yüzyıl University Science, Social and Non-Invasive Health Sciences Research Ethics Committee approved this retrospective cohort study (Date: 05.04.2021, Decision No: 2021/04-649). All procedures were carried out in accordance with the ethical rules and the principles of the Declaration of Helsinki.

Adult patients who underwent LDKT developed mortality within the $1^{\text {st }}$-year were recruited in our center between 2008 and 2020. We had a similar number of adult patients with similar primary kidney disease as the control group. As donor and recipient characteristics, age, gender, BMI $\left(\mathrm{kg} / \mathrm{m}^{2}\right)$, relationship status (related/unrelated), duration of dialysis (months), primary disease that makes end stage renal disease (ESRD), recipient-DM, recipient-HT, recipientCVD, Class I-II panel reactive antibody (PRA), human leukocyte antigen (HLA) mismatch number, induction therapy, total dose of rabbit anti-thymocyte globulin (rATG), and biopsy-proven acute rejection (BPAR) were recorded. The cause of death was recorded for the mortality-group.

\section{Statistical Analysis}

Numerical variables by descriptive statistical analysis were evaluated for whether they were distributed normal or not (Kolmogorov Smirnov/Shapiro-Wilk). Groups were compared in terms of donor and recipient characteristics. Groups were compared by Independent Sample t-test in terms of normally distributed numerical variables. In contrast, groups were compared by Man Whitney-U test for numerical variables that were not normally distributed. Groups were compared by ChiSquare analysis in terms of categorical variables. Fisher Exact and Pearson Chi-Square were used for categorical variables when they did not fit the Chi-Square goodness. The risk factors that have an adjusted effect on $1^{\text {st-year }}$ mortality after kidney transplantation were evaluated by cox regression survival analysis. Numerical variables that were found to be significant by the Receiver Operating Characteristic (ROC) were evaluated to determine predictive accuracy in terms of $1^{\text {st }}$-year mortality. $\mathrm{p}<0.05$ was considered statistically significant.

\section{RESULTS}

The number of patients who underwent LDKT between 2008 and 2020 in our center were 2143 . While our center's total mortality incidence was $8.35 \%(\mathrm{n}=179)$, the $1^{\text {st }}$-year mortality incidence was $1.67 \%(\mathrm{n}=36)$. There was no difference in mean donor age among the groups (45 years vs. 47 years). In the mortality-group, female gender was found to be higher, $63.9 \%(\mathrm{p}=0.003)$. In the mortality-group, donor median BMI was higher, $27.8 \mathrm{~kg} / \mathrm{m}^{2}(\mathrm{p}=0.044)$. In the mortality-group, recipient mean age was higher than the group with no-mortality (53 vs. 43 ), $\mathrm{p}=0.002$. There was no difference between the groups in terms of recipient BMI and gender. Preemptive kidney transplantation rate was lower in the mortality-group ( $16.7 \%$ vs. $44 \%), \mathrm{p}=0.008$. When evaluated in terms of dialysis duration, medianduration (13 months vs. 3 months) was longer in the mortality-group, $p=0.022$. CVD was more common in the mortality-group ( $50 \%$ vs. $31.1 \%$ ), $\mathrm{p}=0.037$. Median HLA mismatch numbers was higher in the mortality-group (4 vs. 3), $\mathrm{p}=0.027$. There was no difference between the groups in terms of primary disease, Class I-I PRA, donor-specific antibody (DSA), induction therapy, rATG total dose and BPAR. The comparison of the groups in terms of donor and recipient characteristics are given in Table $\mathbf{1}$.

\begin{tabular}{|c|c|c|c|}
\hline & \multicolumn{2}{|c|}{ Mortality at 1 Year } & \multirow[b]{2}{*}{$\mathbf{p}$} \\
\hline & Yes (36) & No $(50)$ & \\
\hline Donor age, years & $45 \pm 14$ & $47 \pm 14$ & 0.272 \\
\hline Donor sex, $\mathrm{f} / \mathrm{m}(\mathrm{m} \%)$ & $23 / 13(36.1 \%)$ & $16 / 34(68 . \%)$ & 0.003 \\
\hline Donor BMI, $\left(\mathrm{kg} / \mathrm{m}^{2}\right)$ & $27.8(21-42)$ & $25.7(18-36)$ & 0.044 \\
\hline Recipient age, years & $53 \pm 13$ & $43 \pm 12$ & 0.002 \\
\hline Recipient sex, f/m (m\%) & $15 / 21(58.3 \%)$ & $25 / 25(50 \%)$ & 0.445 \\
\hline Recipient BMI, $\left(\mathrm{kg} / \mathrm{m}^{2}\right)$ & $26.3 \pm 6$ & $25.78 \pm 5$ & 0.730 \\
\hline Relative, yes\% & $20(55.6 \%)$ & $29(58 \%)$ & 0.821 \\
\hline $\begin{array}{l}\text { Dialysis/Preemptive, } \\
\text { Dialysis \% }\end{array}$ & $30 / 6(83.3 \%)$ & $22 / 28(56 \%)$ & 0.008 \\
\hline RRT duration, months & $13(0-228)$ & $3(0-156)$ & 0.022 \\
\hline $\begin{array}{l}\text { Primary disease } \\
\text { - DM } \\
\text { - HT } \\
\text { - Chr.Gn } \\
\text { - Other }\end{array}$ & $\begin{array}{c}13(34.3 \%) \\
6(17.1 \%) \\
5(14.3 \%) \\
12(34.3 \%)\end{array}$ & $\begin{array}{c}10(20 \%) \\
7(14 \%) \\
9(18 \%) \\
24(48 \%)\end{array}$ & 0.331 \\
\hline CVD, yes\% & $18(50 \%)$ & $14(31.3 \%)$ & 0.037 \\
\hline HLA mismatch & $4(2-6)$ & $3(0-6)$ & 0.027 \\
\hline Class I PRA, yes $\%$ & $8(22.2 \%)$ & $11(22.4 \%)$ & 0.980 \\
\hline Clas II PRA, yes\% & $12(33.3 \%)$ & $12(24.5 \%)$ & 0.371 \\
\hline DSA, yes $\%$ & $4(11.7 \%)$ & $7(14.3 \%)$ & 0.753 \\
\hline $\begin{array}{l}\text { Induction } \\
\text { - Bsx } \\
\text { - rATG } \\
\text { - rATG+TPE }\end{array}$ & $\begin{array}{c}0(0 \%) \\
31(86.1 \%) \\
5(13.9 \%)\end{array}$ & $\begin{array}{c}1(2 \%) \\
44(88 \%) \\
5(10 \%)\end{array}$ & 0.606 \\
\hline rATG total dose, mg & $950(0-2200)$ & $300(0-1900)$ & 0.263 \\
\hline $\begin{array}{l}\text { BPAR } \\
\text { - No } \\
\text { - ATCMR } \\
\text { - AAMR } \\
\end{array}$ & $\begin{array}{l}27(75 \%) \\
5(13.9 \%) \\
4(11.1 \%)\end{array}$ & $\begin{array}{c}34(68 \%) \\
9(18 \%) \\
7(14 \%)\end{array}$ & 0.779 \\
\hline $\begin{array}{l}\text { BMI: Body mass index, RRT: } 1 \\
\text { Hypertension, Chr.Gn: Chron } \\
\text { HLA: Human lokocyte antiger } \\
\text { antibody, Bsx: Basiliximab, rA } \\
\text { plasma exchange, BPAR: biops } \\
\text { mediated rejection, AAMR: A }\end{array}$ & $\begin{array}{l}\text { plasman tedaiv } \\
\text { erulonephritis, } \\
\text { Panel reactive } \\
\text { bit antithmocy } \\
\text { in acute rejectio } \\
\text { tibody mediatec }\end{array}$ & $\begin{array}{l}\text { M: Diabetes m } \\
\text { O: Cardiovascul } \\
\text { ody, DSA: Don } \\
\text { obulin, TPE: Th } \\
\text { TCMR: Acute T } \\
\text { ection }\end{array}$ & $\begin{array}{l}\text { us, HT: } \\
\text { isease, } \\
\text { pecific } \\
\text { peutic } \\
\text { li }\end{array}$ \\
\hline
\end{tabular}




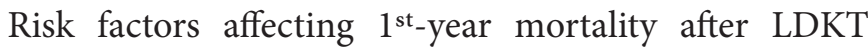
were evaluated by cox regression analysis. Results are given in Table 2. As a result of univariate analysis, donor gender, donor BMI, recipient age, dialysis, and HLA mismatch were determined as statistically significant factors. When these risk factors were evaluated together in model 1, recipient age and dialysis were independent risk factors. When statistically significant variables $(\mathrm{p}<0.25)$ in univariate analysis were analyzed in model 2, recipient age, dialysis and HLA mismatch number were independent risk factors in terms of $1^{\text {st }}$-year mortality. According to Model 1, in terms of $1^{\text {st }}$-year mortality, each 1 year increment in recipient's age increases the mortality by 1.034 times, and dialysis treatment increases the mortality 2.5 times. According to Model 2, in terms of $1^{\text {st }}$-year mortality, each 1 year increment in recipient's age increase the mortality by 1.039 times, dialysis treatment increases the mortality 2.8 times and each 1 mismatch increase in HLA mismatch numbers increases the mortality by 1.3 times.

Receiver operating characteristic analysis showed that the moderate predictive power for recipient age was AUC 0.734 (95\% CI 0.623-0.844, $\mathrm{p}<0.001)$ and the weak level predictive power AUC was 0.639 (95\% CI 0.519-0.759, $\mathrm{p}=0.030$ ) for HLA mismatch. In Figure 1, the ROC curves of these variables are given. The recipient age cut off value was $\geq 50$ years and the HLA mismatch number was $\geq 3$.
For the recipient age cut off value ( $\geq 50$ years), sensitivity was $66.7 \%$, specificity $72 \%$, negative predictivite (NPV) $75 \%$, positive predictivity (PPV) $63.2 \%, \mathrm{p}<0.001$. For the HLA mismatch cut off value $(\geq 3)$, the sensitivity was $34 \%$, specificity $88.9 \%$, NPV $81 \%$, PPV $49.2 \%$, p $<0.015$.

In the mortality-group, we found cause of death rates $55.6 \%$ infection, $30.5 \%$ cardiovascular, $5.6 \%$ cerebrovascular event and $8.3 \%$ others.

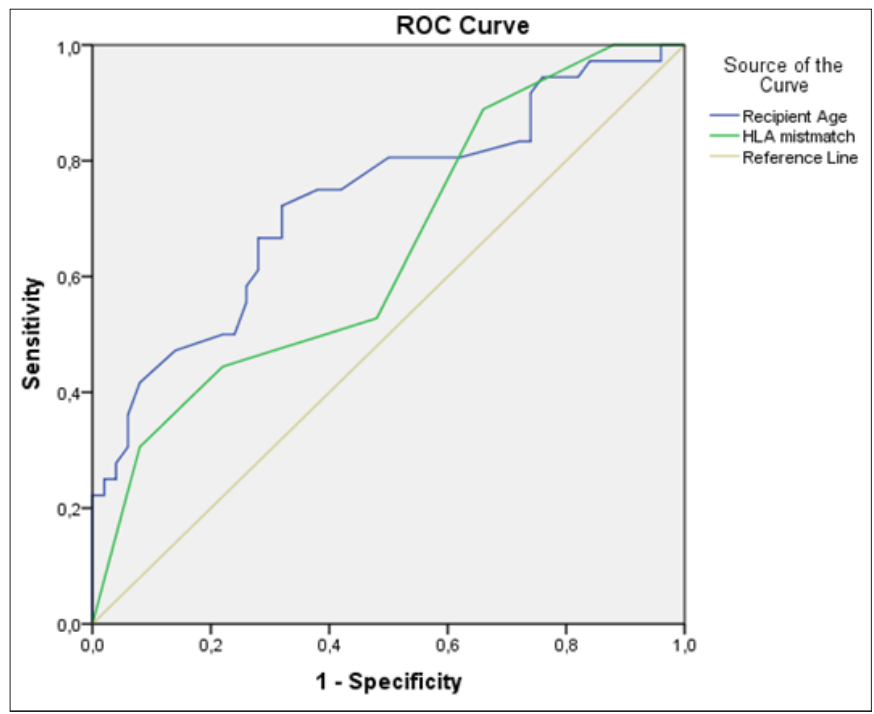

Figure 1. Receiver operating curve for recipient age and HLA mismatch

\section{Table 2. Univariable and multivariable cox regression analysis for $1^{\text {st }}$-year mortality}

\begin{tabular}{|c|c|c|c|c|c|c|}
\hline \multirow{2}{*}{$\begin{array}{l}1^{\text {st }} \text {-year mortality } \\
\text { (Cox regression) }\end{array}$} & \multicolumn{2}{|l|}{ Univariable } & \multicolumn{2}{|c|}{ Multivariable-Model $1(p<0.001)$} & \multicolumn{2}{|c|}{ Multivariable-Model $2(p<0.001)$} \\
\hline & HR (95\% CI) & $\mathbf{P}$ & HR (95\% CI) & $\mathbf{P}$ & HR (95\% CI) & $\mathbf{P}$ \\
\hline Donor age & $0.993(0.970-1.017)$ & 0.580 & & & & \\
\hline Donor sex & $2.545(1.287-5.033)$ & 0.007 & $1.887(0.920-3.867)$ & 0.083 & $1.772(0.843-3.724)$ & 0.131 \\
\hline Donor BMI & $1.074(1.010-1.143)$ & 0.024 & $1.047(0.980-1.118)$ & 0.176 & $1.044(0.976-1.116)$ & 0.214 \\
\hline Recipient age & $1.055(1.024-1.086)$ & 0.000 & $1.034(1.005-1.064)$ & 0.022 & $1.039(1.003-1.076)$ & 0.033 \\
\hline Recipient sex & $0.748(0.385-1.451)$ & 0.390 & & & & \\
\hline Recipient BMI & $1.022(0.957-1.091)$ & 0.514 & & & & \\
\hline Relative & $0.951(0.493-1.836)$ & 0.881 & & & & \\
\hline RRT/Preemptive & $2.852(1.185-6.863)$ & 0.019 & $2.568(1.059-6.225)$ & 0.037 & $2.791(1.082-7.201)$ & 0.034 \\
\hline Diaylsis duration & $1.005(0.999-1.010)$ & 0.097 & & & $0.998(0.992-1.005)$ & 0.583 \\
\hline $\mathrm{DM}$ & $1.563(0.792-3.086)$ & 0.198 & & & $0.852(0.392-1.852)$ & 0.686 \\
\hline Hypertension & $0.575(0.239-1.381)$ & 0.216 & & & $0.800(0.315-2.031)$ & 0.639 \\
\hline CVD & $1.863(0.968-3.586)$ & 0.063 & & & $1.027(0.481-2.190)$ & 0.946 \\
\hline HLA mismatch & $1.297(1.040-1.617)$ & 0.021 & $1.270(0.994-1.623)$ & 0.056 & $1.280(1.002-1.635)$ & 0.048 \\
\hline Class I PRA & $0.915(0.417-2.008)$ & 0.824 & & & & \\
\hline Clas II PRA & $1.246(0.622-2.496)$ & 0.534 & & & & \\
\hline $\begin{array}{l}\text { Induction } \\
\text { • rATG } \\
\text { - rATG+TPE }\end{array}$ & $\begin{array}{l}\text { Reference category } \\
1.205(0.468-3.102\end{array}$ & 0.699 & & & & \\
\hline ATG total dose & $1.000(0.988-1.001)$ & 0.675 & & & & \\
\hline $\begin{array}{l}\text { BPAR } \\
\text { • No } \\
\text { • ATCMR } \\
\text { - AAMR }\end{array}$ & $\begin{array}{l}\text { Reference category } \\
0.773(0.298-2.008) \\
0.738(0.258-2.109)\end{array}$ & $\begin{array}{l}0.598 \\
0.570\end{array}$ & & & & \\
\hline
\end{tabular}




\section{DISCUSSION}

In this study, $1^{\text {st }}$-year mortality of the patients who underwent LKDT in our center was 1.67\%. TSN 2019 registry reports revealed that $1^{\text {st }}$-year mortality $2.85 \%$ (9), US 2019 registry reports revealed that $1^{\text {st }}$-year mortality 2\% (10), European Renal Association-European Dialysis, and Transplant Association (ERA-EDTA) 2017 reports showed that $1^{\text {st }}$-year mortality $1.2 \%$ (11), which was also very similar to our results. This study showed that recipient age, dialysis treatment and HLA mismatch numbers are independent risk factors for $1^{\text {st }}$-year mortality after LDKT. We found cause of death rates was infection (55.6\%) and cardiovascular (30.5\%), the second most common causes of mortality in the mortality-group at one year.

Although the mortality rate due to CVD has decreased in kidney transplant patients compared to dialysis patients, it is still higher than in the general population (3). In kidney transplant patients, CVD-related mortality is 2 times higher than the general population since non-classical risk factors such as proteinuria and decreased Glomerular filtration rate (GFR) is more common in addition to DM, HT, HL, which are the classical risk factors for CVD (3). Wu et al. (12) found a 2-year patient survival rate of $94.7 \%$, and $\mathrm{HF}$ and DM were found as independent risk factors for transplant failure (considered as graft loss and/or patient death). Fuggle et al. (13) showed in their reports that come from the United Kingdom (UK), $1^{\text {st }}$-year survival after LKDT was found to be $99 \%$. Donor age (especially $>60$ years) and recipient-DM as independent risk factors for $3^{\text {th }}$-year mortality after LKDT were determined. In contrast, recipient age and HLA mismatch numbers were not as independent risk factors for $3^{\text {th }}$-year mortality. In that study, in terms of recipient CVD, dialysis duration and preemptive transplantation were not evaluated. Although we found a difference in CVD between the mortalitygroup and the control group in our study, we found that the presence of CVD in the recipient did not affect the $1^{\text {st }}$-year mortality. However, independent risk factors for $1^{\text {st }}$-year mortality were recipient age, dialysis treatment and HLA mismatch numbers. We found the recipient age cut off value of $\geq 50$ years to be moderately discriminating for $1^{\text {st }}$ year mortality. Also, we found $\geq 3$ HLA mismatch numbers to be poorly discriminate in terms of $1^{\text {st }}$-year mortality. We think that the organ transplant team should consider patients of $\geq 50$ years aged and with HLA mismatches $\geq 3$ as risky in terms of development of $1^{\text {st }}$-year mortality and evaluate these patients from this perspective.

Studies show that preemptive kidney transplantation is associated with better graft and patient outcomes in both deceased-donor kidney transplantation (DDKT) and $\operatorname{LDKT}(14,15)$. In TSN 2019 registry reports (9), preemptive kidney transplantation rate in DDKT was limited to $3.6 \%$, while it was $57.4 \%$ in patients with LDKT. In our country, we think that the rate of preemptive transplantation has increased, as the experience of LDKT has grown over the years in organ transplant centers. Our study shows that dialysis treatment increased $1^{\text {st }}$-year mortality by 2.7 times compared to preemptive kidney transplantation. As the time spent on dialysis increases, many defects in the immune system and chronic inflammation explain why CVDs are seen more frequently in dialysis patients and transplant patients. Moreover, it has been shown that chronic inflammation starts much earlier in predialysis CKD stage III-IV patients as a result of the decrease in the clearance of circulating proinflammatory cytokines and the prolongation of the half-lives of these cytokines. We think that preemptive kidney transplantation is an appropriate approach to protect CKD patients from the negative consequences of this uremic milieu and save them by preventing their exposure to dialysis.

In this study, we found the rates of $1^{\text {st }}$-year mortality causes (infection 55.6\%, cardiovascular 30.5\%, cerebrovascular event 5.6\%) similar to the national data given in the TSN 2019 registry reports (9) (infection $46.6 \%$, cardiovascular $26.1 \%$, cerebrovascular event $4.85 \%$ ).

This study has some limitations. Being a single-center study may not be sufficient to represent national results as the organ transplant team performs similar preferences in the kidney transplantation process. The control group may not represent the whole population since all LDKT patients' data couldn't be provided. Identifying specific subgroups of CVDs, which are the most common cause of mortality after kidney transplantation, would help analyze the causes of mortality better before and following transplantation.

\section{CONCLUSSION}

This study has shown that the $1^{\text {st }}$-year mortality results of our organ transplant center are similar to the national and international literature. We determined recipient age, dialysis treatment and HLA mismatch numbers as independent risk factors affecting $1^{\text {st }}$-year mortality after LDKT. We think that encouraging end stage renal disease (ESRD) patients to have preemptive transplantation without dialysis treatment and upgrading the conditions in this respect will reduce mortality in the early period after LDKT.

\section{ETHICAL DECLARATIONS}

Ethics Committee Approval: Yeni Yüzyll University Science, Social and Non-Invasive Health Sciences Research Ethics Committee approved this retrospective cohort study (Date: 05.04.2021, Decision No: 2021/04-649). 
Informed Consent: Because the study was designed retrospectively, no written informed consent form was obtained from patients.

Referee Evaluation Process: Externally peer-reviewed.

Conflict of Interest Statement: The authors have no conflicts of interest to declare.

Financial Disclosure: The authors declared that this study has received no financial support.

Author Contributions: All of the authors declare that they have all participated in the design, execution, and analysis of the paper, and that they have approved the final version.

\section{REFERENCES}

1. Feehally J, Floege J, Tonelli M, Johnson RJ. Comprehensive Clinical Nephrology, $6^{\text {th }}$ ed. Elsevier; 2019. P 939-940, 942-947.

2. Düsing P, Zietzer A, Goody PR, et al. Vascular pathologies in chronic kidney disease: pathophysiological mechanisms and novel therapeutic approaches. J Mol Med (Berl) 2021; 99: 335-8.

3. Sarnak MJ, Levey AS, Schoolwerth AC, et al. American Heart Association Councils on Kidney in Cardiovascular Disease, High Blood Pressure Research, Clinical Cardiology, and Epidemiology and Prevention. Kidney disease as a risk factor for development of cardiovascular disease: a statement from the American Heart Association Councils on Kidney in Cardiovascular Disease, High Blood Pressure Research, Clinical Cardiology, and Epidemiology and Prevention. Hypertension 2003; 42: 1050-65.

4. Yazbek DC, de Carvalho AB, Barros CS, et al. Cardiovascular disease in early kidney transplantation: comparison between living and deceased donor recipients. Transplant Proc 2012; 44: 3001-6.

5. Feehally J, Floege J, Tonelli M, Johnson RJ. Comprehensive Clinical Nephrology, $6^{\text {th }}$ ed. Elsevier; 2019. P 1198-1205, 12131216.

6. Türkiye'de, Nefroloji-Diyaliz ve Transplantasyon. Registry 2008. İstanbul: Pasifik Reklam ve Tanitım Hizmetleri/Metris Matbaacılık, 2009 (Türk Nefroloji Derneği Yayınları).

7. Türkiye'de, Nefroloji-Diyaliz ve Transplantasyon. Registry 2013. Ankara: Miki Matbaacılık San. ve Tic. Ltd. Şti., 2014 (Türk Nefroloji Derneği Yayınları).

8. Türkiye'de, Nefroloji-Diyaliz ve Transplantasyon. Registry 2016. Ankara: Miki Matbaacılık San. ve Tic. Ltd. Şti., 2017 (Türk Nefroloji Derneği Yayınları).

9. Türkiye'de, Nefroloji-Diyaliz ve Transplantasyon. Registry 2019. Ankara: Miki Matbaacılık San. ve Tic. Ltd. Şti., 2020 (Türk Nefroloji Derneği Yayınları).

10. Hart A, Smith JM, Skeans MA, et al. Organ Procurement and Transplantation Network (OPTN) and Scientific Registry of Transplant Recipients (SRTR). OPTN/SRTR 2018 Annual Data Report. Am J Transplant 2020; 20: 20-130.

11.Kramer A, Boenink R, Noordzij M, et al. The ERA-EDTA Registry Annual Report 2017: a summary. Clin Kidney J 2020; 13: 693-709.

12.Wu DA, Robb ML, Forsythe JLR, et al. Recipient Comorbidity and survival outcomes after kidney transplantation: a UK-wide prospective cohort study. Transplantation 2020; 104: 1246-55.

13. Fuggle SV, Allen JE, Johnson RJ, et al. Factors affecting graft and patient survival after live donor kidney transplantation in the UK. Transplantation 2010; 89: 694-701.
14.Jay CL, Dean PG, Helmick RA, Stegall MD. Reassessing preemptive kidney transplantation in the United States: are we making progress? Transplantation 2016; 100: 1120-7.

15. Kasiske BL, Snyder JJ, Matas AJ, Ellison MD, Gill JS, Kausz AT. Preemptive kidney transplantation: the advantage and the advantaged. J Am Soc Nephrol 2002; 13: 1358-64.

16. Feehally J, Floege J, Tonelli M, Johnson RJ. Comprehensive Clinical Nephrology, 6th ed. Elsevier; 2019. P 967-971. 